\title{
Function-Based vs. Meaning-Based Beliefs in Teaching Vocabulary
}

\author{
Mozhgan Alsadat Ghaffarzadeh Hassankiadeh, Islamic Azad University (Tonekabon Branch), Iran \\ Article received 3 August 2012, Final version received 23 October 2012
}

\begin{abstract}
Teachers are highly influenced by their beliefs, which are related to their ideas, to their views of the world and to their values and conceptions of their environment. Departing from the premise that teachers' beliefs are one of the most significant issues in education, this study investigates the effects of language teachers' beliefs about teaching vocabulary on learners' vocabulary intake in language learning classrooms. The research attempts to identify which one of the teachers' lexicon teaching beliefs is more effective in enhancing learners' vocabulary intake. The beliefs which are under question are divided into two groups: meaning-based and function-based beliefs about teaching lexicon. The study looks at the effect of teachers' actions (related according to their stated beliefs) on learning vocabulary by Iranian EFL learners. The findings indicate that: a) the learners who were taught by teachers that placed more emphasis on function-based beliefs are more successful in learning lexicon than those who were taught by teachers focusing more on meaningbased beliefs; b) the result is the same for both genders.
\end{abstract}

\section{Introduction}

This study investigates the effects of teachers' beliefs about teaching lexicon on learners' vocabulary intake. The study of teachers' beliefs forms a part of the process of understanding how teachers conceptualize their work. In order to understand these conceptualizations, it is necessary to understand the beliefs and principles they operate from (Richards, Gallo, \& Renandya 2001). According to Lortie (2002), teachers bring with them prior beliefs about teaching vocabulary; these beliefs are formed through previous experience and observation (such as occurs as students and during teacher internships) which then has an impact on the way in which they design participation in and situations for facilitating learning of lexicon. In short, how teachers have seen and experienced vocabulary learning will affect their beliefs and subsequent actions in teaching lexicon. Lexicon is an important domain in the process of learning a language and should be considered as significant part of teaching and learning languages. Thus, the present study aims at investigating the relationship between these two fields in language teaching.

During the last two decades, teacher education research has made significant advances in 
studying teacher beliefs, and the connection between teacher beliefs and educational practice has already been well established (Borg, 2003; 2012). But there has been little or no attention to the effect of teachers' beliefs on their learners' vocabulary acquisition. In this study, the aim is to fill the gap and to find the relationship between teacher beliefs and learners' amount of lexicon intake.

About vocabulary and its significance in learning a language it can be said that limited knowledge of English vocabulary may affect the school performance of English language learners (Cummins, 1994). During the past decade, researchers and academics have pointed to the importance of vocabulary acquisition for second language (L2) learners (Allen, 1983; Laufer, 1986; Nation, 1990; Richards, 1980). Thus, along these lines, this article aims at studying these two significant issues in language teaching/learning. Studying lexicon teaching beliefs will be useful in teacher education in order to help future teachers explore more helpful ways to promote learners' lexicon intake.

\section{Teachers' Beliefs about Teaching Lexicon}

In a study in 2001 (Richards, Gallo \& Renandya), beliefs were found to be far more influential than knowledge in determining how individuals organize and define tasks and problems, and were better predictors of how teachers behaved in the classroom than other factors. According to Thomas \& Harri-Augstein (1983), teachers' beliefs are important, since they open a whole new vision of personal beliefs, myths, and understandings of how they behave in the classroom, especially given that, as Arnold (1999) points out, beliefs shape the way humans perceive everything around them and act as strong filters of reality. Teachers' beliefs about the learning process are "of crucial importance to the success or failure of learners' efforts to master a foreign language" (Rifkin, 2000, p. 394).

Teachers' belief is a central construct which deals with human behavior and influence teachers' consciousness, teaching attitude, teaching methods, teaching policies, teaching behavior and learners' development (Horwitz, 1985). Consequently, for the past 20 years, the dominant approach to investigating student-teachers' instructional intentions has been to measure their pedagogical beliefs (cf. Brookhart\& Freeman, 1992; Chan \& Elliot, 2004; Minor, Onwuegbuzie, Witcher, \& James, 2001; Ozgun-Koca \& Sen, 2006), as well as teachers' self-efficacy beliefs (Brand \& Wilkins, 2007; Palmer, 2006) and their diversity beliefs (Milner, 2005; Pohan \& Adams, 2007). Scholars argue that beliefs are important to teacher educators because they influence 
teachers' classroom practice, including their methods of delivering instruction (Kagan, 1992; Pajares, 1992). Research focused on pedagogical beliefs in particular suggests that many beginning teachers view teaching as telling or lecturing that is, directly transmitting information to a passive learner (Brookhart\& Freeman, 1992; Holt-Reynolds, 1992; Richardson, 1996; Torff, 2003).

Research in the area provides ample evidence that teacher thinking influences teachers' perceptions, which, in turn, form teacher's beliefs that affect their classroom performance (Bhasin \& Baveja, 2010). Different teacher beliefs will lead to different ways of classroom management, different teaching strategies, different practices and subsequently differences in the amount of learner intake.

Inevitably, learner intake is directly related to vocabulary learning, underlining the importance of looking at research into vocabulary learning. Vocabulary learning is widely regarded as a crucial task for second language learners in their attempts to improve linguistic competence (Brown \& Perry, 1991; Gu, 2003, 2005).Research suggests that vocabulary is enormously important to children's development, especially in reading. Research clearly indicates that children with larger vocabularies have higher school achievement in general (Smith, 1941, cited in Beck, McKeown, \&Kucan, 2002) and higher reading achievement in particular (Anderson \& Freebody, 1981; Graves, 1986; Stahl, 1998). In fact, some studies have related people with larger vocabularies with have higher IQs (Bell, Lassiter, Matthews, \& Hutchinson, 2001; Hodapp \& Gerken, 1999). Research shows that teachers can do things that significantly increase students' vocabularies (Baumann, Kame'enui, \& Ash, 2003; Blachowicz \& Fisher, 2000; National Reading Panel, 2000; Stahl \& Fairbanks, 1986), and by doing so children's reading comprehension will also improve (National Reading Panel, 2000; Stahl, 1998).

Schmitt's (1997) study on vocabulary strategy survey looked at vocabulary learning strategy groups. The identification of those groups suggests the existence of specific strategies for discovering the meaning of new word and for consolidating a word once it has been encountered. As indicated in the studies cited on teaching beliefs, exposure to different learning strategies can lead to new beliefs. Clearly, vocabulary knowledge is critical to study the issues which are related to vocabulary intake. Turning now to teachers' beliefs regarding vocabulary teaching, this article first outlines the differences between teaching beliefs concerning memory, meaning and function-based vocabulary teaching. 
Memory, Meaning and Function-Based Teaching Beliefs: In this research, the focus is on two kinds of teachers' beliefs about teaching vocabulary that will be called meaning-based and functionbased, however the effect of memory-based beliefs cannot be ignored, this area was also covered in the questionnaire. Memory-based belief refers to concentrating on memorizing words, analyzing the parts of speech, focusing on affixes, listening and repeating, writing and practicing, imagining the written forms of the words and connecting the words with their synonyms and antonyms. The results of the questionnaire indicate that the teachers in this group believe that using keyword methods to memorize the words, concentrating on the form of the words and using strategies to remember the words (without much attention to meaning) is an effective teaching approach to vocabulary. To exemplify: supposing that a teacher wants to teach the word "snow", memory-based teaching implies that the teacher may use a list of the words which are in the same family with the selected word (such as snowy, snowing,...) or present some synonyms, antonyms, words derivations or affixes and then ask the learners to memorize them.

In contrast, meaning-based belief refers to negotiation of the meaning of words through the use of objects, mental images, etc., helping the learner to make connections between words within 'lexical families' in learners' minds. If a teacher believes in meaning-based teaching, he or she may use some pictures to clarify the meaning or may ask the learners to bring to mind a memory of a snowy day or perhaps ask the learners, in groups, to try to find out the meaning of the word by consulting resources such as a dictionary.

Function-based belief refers to the negotiation of meaning through the application of words in sentences and texts, or through activities that help the learner understand the targeted words better and to make relationships between the words and the learners' own experiences. A teacher who believes in function-based teaching might ask the learners to go outside and touch the snow or if this is not possible the teacher might ask them to 'create a snowy day' in the classroom, using as many resources as possible, in order to help them imagine what it would be like to walk outside on such a day (Ghaffarzadeh, 2012).In other words, it is an approach that uses the learners' energy for learning instead of just imagining the words (Ibid, 2012). 


\section{Data compilation: Context and Participants}

Participants: The focal data stemmed from the participation of 100 English as a Foreign Language (herein EFL) junior high school learners (both male and female; grade 3)1 and two teachers. The teachers and students in the study gave their consent to participate. The student subject group was selected out of approximately 150 EFL students in the same grade in junior high schools in Nowshahr, Mazandaran, Iran. All of 100 students began the academic year at the same level of language proficiency as determined by the vocabulary Instruction Orientation Survey (OPT)2. The students were divided into two groups of 50 learners, with a teacher for each group.

Two teachers (one for each group) were chosen to participate in the study. The learners were selected randomly based on the Krejeie and Morgan's (1970)3 table for identifying the number of samples from a statistical community. In selecting the teachers, 30 EFL teachers were randomly asked to participate by filling in a questionnaire and then two out of the thirty were chosen for the study, based on their answers to the questions; the two teachers with the highest score in items in the questionnaire belonging to categorized beliefs were selected to participate (for example, the teacher who scored highest by indicating beliefs in meaning-based strategies for teaching was selected to represent the teacher of the meaning-based group (see more detail of questionnaire design and grouping below).

\section{Data compilation instruments: Teachers Questionnaire and Learners Vocabulary Test}

The questionnaire: This study used a questionnaire designed to illustrate beliefs concerning how to teach lexicon. The adoption of a questionnaire as a tool for data collection in studies on beliefs is a common practice (Horwitz, 1985). In this study the questionnaire was used for categorizing the teachers into groups, followed by a vocabulary test given to the students who had been taught by the teachers as a tool to identify the results of the teachers' beliefs. A questionnaire was chosen for several reasons, one of them being the practicality and ease of use; "by administering a questionnaire to a group of people, one can collect a huge amount of information in less than an hour" (Dörnyei, 2003). Deriving results from questionnaires can be further facilitated through the use of computers and applied software. Another feature of a questionnaire is its anonymity, which may relieve the participants of stress related to answering personal questions (Ghaffarzadeh, 2012).

The questions derived from a previous survey of 30 EFL teachers in which the teachers were 
asked to explain, in writing, their beliefs about teaching lexicon (the teachers were selected randomly from Nowshahr and Chaloos, two cities in Mazandaran, Iran). The descriptions were then categorized into types of beliefs. These categories were then evaluated and modified by seven experienced, Iranian EFL teachers to ensure that the categories were appropriate for measuring lexicon teaching beliefs in the Iranian context. The categories underlined practices that fell within the boundaries of memory, meaning and function-based beliefs concerning the teaching of lexicon.

To confirm the reliability and validity of the questionnaire, ten experienced, Iranian EFL teachers (different with the teachers who had evaluated the questionnaire for appropriateness) to mark the questionnaire. The ten experts calculated the content validity as equal to $87 \%$. Following this, the questionnaire was given to a group of teachers to identify the reliability; using Cronbach's Alpha, the reliability was estimated as $93 \%$, thus allowing the researcher to conclude that the questionnaire was appropriate for use as a tool to measure teachers' beliefs about approaches to teaching and learning lexicon.

All of the teaching beliefs are not limited to categories as delineated in the literature research. Teachers innovate when teaching, they produce new strategies, and new beliefs may emerge. So, it is necessary to triangulate with factors that go beyond measurement in humanistic studies on as teaching beliefs (Ghaffarzadeh, 2012). As the mentioned previously, 98\% of teachers' beliefs represented in the study were derived from a survey of teachers of Nowshahr and Chaloos (two cities in Mazandaran, Iran).

Once the categories had been organized, one teacher who had been assigned to Meaningbased lexicon teaching was selected (see explanation of questions and their categories below), and the teacher who was assigned more on function-based strategies was chosen as focus points of the study so that a comparison of learners' results and teacher beliefs could be made.

Memory-Based Group Questions: Respondents who replied affirmatively to questions 5, 9, $10,11,12,16,17,19,26,27,30,31$ and 35 (see Appendix A) were assigned to the memory-based group that concentrates on memorizing words, analyzing the parts of speech, focusing on affixes, listening and repeating, writing and practicing, imagining the written forms of the words and connecting the words with their synonyms and antonyms. The teachers in this group believe in using keyword methods to memorize words, concentrating on the form of the words and using strategies to remember the words with minimum attention to understanding the meaning of the word. 
Meaning-Based Group Questions: Respondents who replied affirmatively to questions 1, 2, $4,6,13,14,18,20,21,23,29,36$ and 39 (see Appendix A) were assigned to the group that focuses on making relationship between the words, images and their the meaning of the word, using mental images and semantic networks. In this group teachers believe more in placing words in a group with other items, paraphrasing the words and finding clues to make correlations between words and their meaning. Other techniques that teachers in this group use are mental images, physical objects and strategies which go beyond getting learners to just memorize and to elaborate meaning.

Function-Based Group Questions: Respondents who replied affirmatively to questions 3, 7, $8,15,22,24,25,28,32,33,34,37$ and 38 (see Appendix A) were assigned to the function-based group that focuses on connecting the words with reality and learners' experiences, making use of common sense and knowledge of the world, using real objects such as reading newspapers or a book and using words in real-life or quasi-real life situations. The teachers in this group believe that an EFL teacher should strategies that require learners to use new words in sentences, to group words within a storyline form, to use physical actions to learn vocabulary, get learners to do specific actions, allow students to self-test, to present more information than is covered in the vocabulary textbook, promote students to associate between words and the text and to use the text to understand unknown words.

Learners' Vocabulary Test: An initial test was used in order to group, homogeneously, the learners in order to ensure the reliability of the results of the vocabulary test. A test is a procedure used to collect data on subjects' ability or knowledge of certain disciplines and in second or foreign language learning research, tests are generally used to collect data about the subject's ability and knowledge of the language in areas such as vocabulary, grammar, reading, metalinguistic awareness, and general proficiency (Seliger \& Shohamy, 1989:176).Vocabulary testing is believed to be a useful element in a teaching program, providing teacher and learner with useful information that can serve each as a basis for improvement (Harrison, 1983; Nation, 1990; Schmitt, 2000).

The main purpose of using a vocabulary test in this study was to measure the learners' progress in learning vocabulary and then to analyze these results in relation to their teacher's beliefs about teaching and learning lexicon. The test consisted of 42 words that the students had to define, without any preliminary preparation for the exam. The test was given to the learners after they had been taught by the teachers in the study for approximately six months.

The vocabulary test was based on the syllabus of Iranian EFL learners who were in grade 
three in senior high schools in Iran, using as a basis the grade 3 textbook as the reference for constructing the test. There are approximately 270 words in this book which the students should learn in a period of eight to nine months. After six months approximately 150 words should have been taught. In this study 42 words were chosen randomly, using a computer, and were given to learners in different groups. The learners were asked to write the meanings of the words in English or Persian.

The test was utilized as an instrument to place all the groups in the same level so that we can measure the effect of independent variable (lexicon teaching beliefs) on the dependent variable (learners' vocabulary size).This test was given to the students before they were taught by the teachers and then administered again after six months in order to identify whether there was any influence on the learners' vocabulary intake or not.

\section{Pilot Study}

Despite the most careful planning, there is no guarantee that a research project will work well in practice (Ghaffarzadeh, 2012). Therefore, for the purpose of this research, a pilot study was used to discern whether the questions would yield the kind of data required and to eliminate any questions which might be ambiguous or confusing to the respondents. Thus all the questions in the instruments (questionnaire and test) were piloted with a small sample of subjects before use with the intended large research group. As Allison et al (1996, p.95) state: "For this purpose you need people who are of ability and background similar to your target population." The pilot subjects were selected from Chaloos, Mazandaran, Iran. Key features of the respondents are summarized in the appendix $\mathrm{C}$ which shows a comparison of pilot study and final study subjects.

For the pilot study, the three instruments explained above were administered to each of the 16 subjects in the pilot study during the educational year in two classes (one belonging to the researcher). The responses to the pilot study confirmed that the results of vocabulary test for the students who had the teacher assigned to the function-based belief teacher (assigned according to the questionnaire, see explanation above) were better than those students who were in the group of the teacher coming from the Meaning-Based group. 


\section{The study}

Answers given in questions in the questionnaire were tabulated and utilized to provide answers to the research questions. After the results of the vocabulary tests were collected the teachers were categorized into two groups based on their answers to the questionnaire. In this study, T-test was used to denominate the answer to the question. Each of the groups of beliefs had 13 items. The total number of items in this questionnaire was 39. The answers by EFL teachers that were given to the questions are shown in table 1.

Table 1. First teacher's answers to each part of the questionnaire

\begin{tabular}{lllllll}
\hline & & $\begin{array}{l}\text { Teacher1 } \\
\text { not at all useful }\end{array}$ & slightly useful & moderately & useful & quite useful \\
useful & Count & Count & Count & Count & Count \\
\multirow{4}{*}{ Belief } & Memo-B & 10 & 3 & 0 & 0 & 0 \\
& M-B & 6 & 5 & 2 & 0 & 0 \\
& F-B & 0 & 0 & 0 & 3 & 10 \\
\hline
\end{tabular}

Based on the data in table 1 and the graph 1 for this teacher which is presented in appendix B, it was concluded that the teacher 1 believes more in Function-Based lexicon teaching because this teacher's negative answers to the group of questions associated with Function-Based group are the lowest and his positive answers to this group are the highest. The mean value of each part of the beliefs in this questionnaire (using the formula of " $5 * 13+13 / 2$ " for calculating the marks in the questionnaire and based on a Likert scale) is 39. If the teacher's answers are superior to this value, it indicates positive beliefs and if it is below the value it shows negative beliefs.

According to table 1, the teacher 1's mark in memory-based teaching is 16, in MeaningBasing the mark is equal 1 to 22 and in Function-Based, his mark is equal to 62; where the scale values are not at all=1, slightly useful=2, moderately useful $=3$, useful $=4$, and quite useful $=5$. As it can be seen, 16 is less than 39, 22 is less than 39 whereas 62 is greater than 39 , so it can be concluded that teacher 1 beliefs about Memory-Based and Meaning-Based teaching are more negative and Function-Based teaching are more positive. 
Table 2. Second teacher's answers to each part of the questionnaire

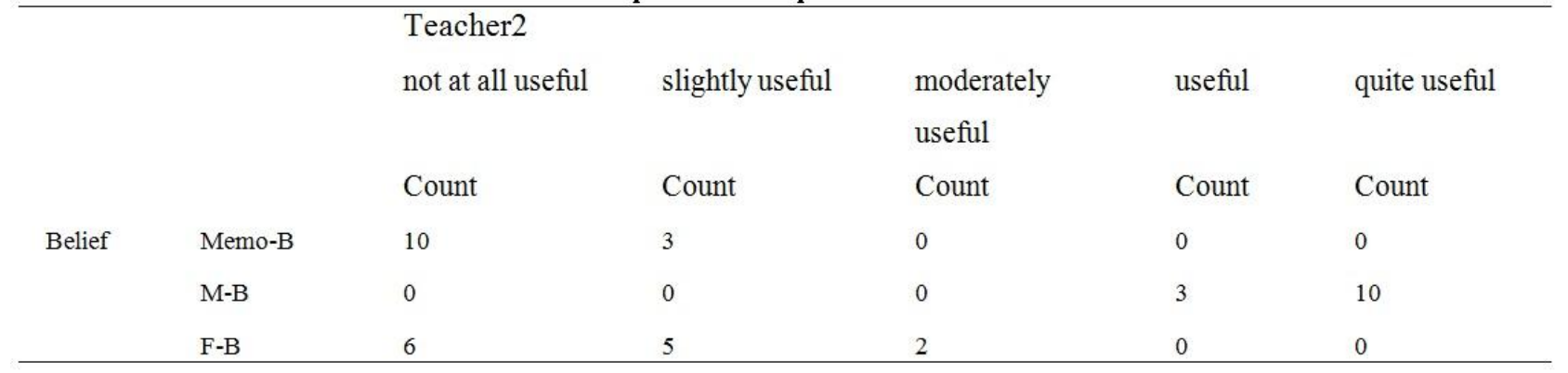

Based on the data in table 2 and the graph 2 for this teacher which is presented in appendix B, it was concluded that teacher 2 believes more on Meaning-Based lexicon teaching. His negative answers to Meaning-Based questions group are the lowest and his positive answers to this group are the highest. As can be seen in table 2, teacher 2's mark in Memory-Based questions is 16, in MeaningBased is 62 and in Function-Based is 22. 16 is less than 39, 22 is less than 39 and 62 is greater than 39, so it was concluded that this teacher believes less in Memory-Based and Function-Based teaching than in Meaning-Based teaching. So teacher 2 was classified in the group of MeaningBased beliefs.

Both teachers scored the same in Memory-Based beliefs and thus were chosen for the study because they are different equally in Function-Based and Meaning-Based scores. Once the two teachers had been categorized it was necessary to organize the learners into these two groups. Learners were distributed equally according to level (all scored similarly in the vocabulary tests) and gender. After six months of normal classes, the learners were asked to give the meanings of 42 words (they could define in English or Persian). These words derived from the course syllabus. Students did not know about the test beforehand. Correctly defined words from the learners in each group were used as criteria for calculating the Mean, standard and other measures.

As can be seen in table 3 the Mean and Standard of learners' marks in each group were identified. 
Table 3. Comparing the statistical calculations of two teachers

\begin{tabular}{|c|c|c|c|c|c|c|}
\hline $\begin{array}{l}\text { the number of } \\
\text { the words that } \\
\text { the learners } \\
\text { have known } \\
\text { their meaning } \\
\text { the effect of lexicon teaching } \\
\text { beliefs in male and female learners }\end{array}$ & Mean & $\mathrm{N}$ & Std. Deviation & Minimum & Maximum & Sum \\
\hline function-based lexicon teaching belief & 39.62 & 50 & 1.497 & 35 & 41 & 1981 \\
\hline meaning-based lexicon teaching belief & 27.44 & 50 & 6.488 & 12 & 38 & 1372 \\
\hline Total & 33.53 & 100 & 7.707 & 12 & 41 & 3353 \\
\hline
\end{tabular}

In table 3 it can be see that the mean of the scores for learners in Function-Based teaching is higher than those in the Meaning-Based group (Function-Based mean=39.62 out of 42 words; MeaningBased group mean=27.44 out of 42 words) signifying that the Function-Based group of learners provided correct meanings for 94.33 percent of that words that were given to them whereas the Meaning-Based group of learners provided only 65.33 percent of correct answers.

\section{Discussion of results}

As it can be recalled, the aim of this research was to find the relationship between teacher beliefs and learners' amount of lexicon intake. The null hypothesis of the study was "there are no differences between lexicon teaching beliefs in promoting learners' lexical intake." Based on the results, since the $\mathrm{t}$ value of 12.936 exceeds the $\mathrm{t}$ critical value of 2.617 at the .01 level of significance for a two tailed test; the null hypothesis is rejected (see table 4).

Table 4. Independent sample T-test

\begin{tabular}{|c|c|c|c|c|c|c|c|c|c|c|}
\hline Independent Sample & & \multicolumn{2}{|c|}{$\begin{array}{l}\text { Levene's Test for } \\
\text { Equality of Variances }\end{array}$} & \multicolumn{7}{|c|}{ t-test for Equality of Means } \\
\hline & & & Sig. & $\mathrm{t}$ & df & $\begin{array}{l}\text { Sig. (2- } \\
\text { tailed) }\end{array}$ & $\begin{array}{l}\text { Mean } \\
\text { Difference }\end{array}$ & $\begin{array}{l}\text { Std. Error } \\
\text { Difference }\end{array}$ & $\begin{array}{l}95 \% \text { Confidence } \\
\text { Interval of the } \\
\text { Difference }\end{array}$ & \\
\hline & & & & & & & & & Lower & Upper \\
\hline $\begin{array}{l}\text { the number of the } \\
\text { words that the } \\
\text { learners have known }\end{array}$ & $\begin{array}{l}\text { Equal } \\
\text { variances } \\
\text { assumed }\end{array}$ & 67.755 & .000 & 12.936 & 98 & .000 & 12.180 & .942 & 10.311 & 14.049 \\
\hline their meaning & $\begin{array}{l}\text { Equal } \\
\text { variances not } \\
\text { assumed }\end{array}$ & & & 12.936 & 54.202 & .000 & 12.180 & .942 & 10.292 & 14.068 \\
\hline
\end{tabular}

In fact, for the entire population of 100 learners the results were $t=12.936$, df $=98$ with $99 \%$ confidence interval. On the basis of the findings of this study, it is possible to draw a conclusion about vocabulary learning by Iranian EFL learners, specifically that the learners who were taught by the teacher with a higher number of answer indicating function-based lexicon teaching beliefs had 
better results in the vocabulary test than those who were taught by the teacher with a higher number of positive answers in questions about Meaning-Based lexicon teaching beliefs. (The result was the same for both male and female learners.) These findings correspond to other studies in language teaching in that they show that "language teachers' classroom practices are shaped by a wide range of interacting and often conflicting factors" (Borg, 2003: 91; also Zheng, 2009; Cohen \& Fass, 2001).

However, this research has aimed to examine more closely the influence of teachers' beliefs on learners' lexicon intakes. The research is focused on teachers' beliefs about teaching vocabulary because understanding the experiences of teachers with varied orientations toward lexicon instruction can provide teacher educators with information to guide the development of future vocabulary methods courses. To conclude, the findings of the data showed it is possible to say that the learners who were taught by teachers with higher scores in Function-Based lexicon teaching belief items in the questionnaire demonstrated better results in lexicon learning than those who were taught by teachers with higher scores in Meaning-Based lexicon teaching belief items, all of which leads to the implication that the Function-Based approach to vocabulary teaching promotes better lexicon intake.

Raising awareness teacher beliefs, especially ones that stem from good teaching strategies, can be helpful in promoting more effective teaching approaches of vocabulary. It is argued here that teacher beliefs in effective teaching approaches of lexicon will lead to better strategies, resulting in more learners with better scores in vocabulary learning.

\section{Limitations of the study}

As it was declared previously, this study investigates just two aspects of lexicon teaching beliefs (Meaning-Based and Function-Based) although it is recognized that other kinds of beliefs may also have an important impact on learning and which have not been stated by the teachers. Since belief is an abstract concept, one of the only sources for measuring it is what people state. Another limitation lies in confirming that the results aptly describe the reality outlined. It is plausible that during the six months of the study, new beliefs were formed in teachers' minds which had some effect on the language learning taking place. Beliefs are changeable; they can be added, omitted or modified during teaching and learning and these factors could result in different outcomes in another study. 
This type of study can be more reliable, if it is a longitudinal, however, due to limitations in time and the conditions of the schools in Iran, the researcher could not carry out a longitudinal study.

As Best \& Kahn (2000) explain, in these kinds of studies the researcher cannot control these conditions; he or she can only monitor the conditions and the probable results on the environment. Similarly, in this study, there is no control on teachers' beliefs; the researcher can only monitor its probable effect on learning as part of an observation of the environment (Best \& Kahn, 2000:119).

\section{Suggestions for further study and final words}

One area for future research deriving from this study is a longitudinal study of teacher belief development. It is one thing to study the way in which teachers' beliefs developed during one semester of vocabulary methods course, but quite another thing to see the long-term impact this has had on teaching practice. Longitudinal data would help build a long-term understanding of the development of beliefs about vocabulary and vocabulary instruction. This study attempted to identify significant episodes in the belief of EFL teachers while they were teaching vocabulary and determine what influence this had on learners' vocabulary intake. Further research is needed to explore the dynamic development of teachers in other areas in learning a language and to develop more profound insights into teachers' beliefs in those areas and their impact on learning. Moreover, research into the impact on learners of other kinds of beliefs (apart from the categories established here) and in different areas in the world is desirable.

\section{References}

Allen, V. F. (1983). Techniques in teaching vocabulary. Oxford: Oxford University Press.

Allison, B., O’Sullivan, T., Owen, A., Rice, J., Rothwell, A.,\& Saunders, C. (1996). Research skills for students. London: Kegan Paul.

Anderson, R.C., \& Freebody, P. (1981).Vocabulary knowledge. In J. Guthrie (Ed.), Comprehension and teaching: Research reviews (pp. 77-117). Newark, DE: International Reading Association.

Arnold, J. (Ed). (1999). Affect in language learning. Cambridge: Cambridge University Press.

Baumann, J. F., Kame'enui, E. J., \& Ash, G. E. (2003). Research on vocabulary instruction: Voltaire redox. In J. Flood, D. Lapp, J. R. Squire, \& J. M. Jensen (Eds.), Handbook of research on teaching the English language arts, Second Edition (pp. 752-785). Mahwah, NJ: Lawrence Erlbaum.

Beck, I. L., McKeown, M. G., \& Kucan, L. (2002). Bringing words to life: Robust vocabulary instruction. New York: Guilford.

Bell, N. L., Lassiter, K. S., Matthews, T. D., \& Hutchinson, M. B. (2001). Comparison of the 
Peabody picture vocabulary test. Third Edition and Wechsler Adult Intelligence Scale Third Edition, with university students. Journal of Clinical Psychology, 57, 417-422. http://dx.doi.org /10.1002/jclp.1024

Best,W.J., \& Kahn,V. J. (2000). Research in education (10 ${ }^{\text {th }}$ Ed.). Boston, MA: Pearson Education:118-119.

Bhasin K. M, \& Baveja B. (2010). Student teachers' thinking about knowledge, learning and learners in India, University of Delhi. Literacy Information and Computer Education Journal (LICEJ); Volume 1 Issue 1:1. Retrieved 12 September 2012 from: http://www.infonomics-society.org/LICEJ/Published\%20papers.htm

Blachowicz, C. L. Z., \& Fisher, P. (2000). Vocabulary instruction. In M. L. Kamil, P. B. Mosenthal, P. D. Pearson, \& R. Barr (Eds.), Handbook of reading research, Volume III (pp. 503-523). Mahwah, NJ: Lawrence Erlbaum.

Borg, S. (2003). Teacher cognition in language teaching: A review of research on what language teachers think, know, believe, and do. Language Teaching, 36: 91. Retrieved 14 September 2012 from:

http://journals.cambridge.org/action/displayAbstract?fromPage=online\&aid=151137.http://d x.doi.org/10.1017/S0261444803001903

Borg, S. (2012). Interview: Teacher cognition and language teacher education: Beliefs and practice. A conversation with Simon Borg. Interview by M. Birello. Bellaterra Journal of teaching \& Learning Language \& Literature, 5(2), 88-94. Retrieved 14 September 2012 from http://revistes.uab.cat/jtl3/article/view/464

Brand, B., \& Wilkins, J. (2007). Using self-efficacy as a construct for evaluating science and mathematics methods courses. Journal of Science Teacher Education, 18(2), 297-317. Retrieved 15 September 2012 from: http://www.citeulike.org/journal/klu-jste/. http://dx.doi.org/ 10.1007/s10972-007-9038-7

Brookhart, S. M., \& Freeman, D. J. (1992).Characteristics of entering teacher candidates. Review of Educational Research, 62(1), 37-60. Retrieved 12 September 2012 from: http://www.jstor.org/action/doBasicSearch?filter=\&Query=\&Search.x $=5 \&$ Search. $y=8 \& w c=$ on

Brown, T. S. \& Perry. F. L. (1991). A comparison of three learning strategies for ESL vocabulary acquisition. TESOL Quarterly; 25: 655-670. http://dx.doi.org /10.2307/3587081

Chan, K., \& Elliot, R. (2004).Relational analysis of personal epistemology and conceptions about teaching and learning. Teaching and Teacher Education, 20, 817-831. http://dx.doi.org/10.1016/j.tate.2004.09.002

Cohen, A. D., \& Fass, L. (2001). Oral language instruction: Teacher and learner beliefs and the reality in EFL classes at a Colombian University. Research report. Department of English and Second Language, University of Minnesota, February 2001.

Cummins, J. (1994). The acquisition of English as a second language. In K. Spangenberg-Urbschat \& R. Pritchard (Eds.), Kids come in all languages: Reading instruction for ESL students (pp. 36-62). Newark, DE: International Reading Association.

Dornyei, Z. (2003). Questionnaires in second language research: Construction, administration, and processing. London: Lawrence Erlbaum.

Ghaffarzadeh Hassankiadeh, M. A. 2012. The effect of teachers' lexicon teaching beliefs on EFL learners' vocabulary Intake. Journal of Education and Learning, 1(2):156-160. http://dx.doi.org/10.5539/jel.v1n2p

Graves, M. F. (1986). Vocabulary learning and instruction. Review of Research in Education, 13: 
49-91. Retrieved 11 September 2012 from: http://www.deepdyve.com/lp/sage/chapter-2vocabulary-learning-and-instruction-0aHUvoPFF7

$\mathrm{Gu}$, P.Y. (2003). Fine brush and freehand: the vocabulary-learning art of two successful Chinese EFL learners. TESOL Quarterly, 37(1): 73-104. http://dx.doi.org /DOI: 10.2307/3588466

$\mathrm{Gu}, \mathrm{P}$. Y. (2005). Vocabulary learning strategies in the Chinese EFL context. Singapore: Marshall Cavendish.

Harrison, A. (1983). A Language testing handbook. London \& Basingstoke: Macmillan Press Ltd.

Hodapp, A. F., \& Gerken, K. C. (1999). Correlations between scores for Peabody Picture

Vocabulary Test-III and the Wechsler Intelligence Scale for Children-III. Psychological

Reports, 84, 1139-1142. Retrieved 9 September 2012 from:

http://ammons.ammonsscientific.com/php/toc1_PR.php

Holt-Reynolds, D. (1992). Personal history-based beliefs as relevant prior knowledge in coursework. American Educational Research Journal; 29(2): 325-349. Retrieved 5 September 2012 from: http://www.deepdyve.com/lp/sage/personal-history-based-beliefs-asrelevant-prior-knowledge-in-course-ZxdT1ZXsMc

Horwitz, E.K., (1985). Using student beliefs about language learning and teaching in the foreign language methods course. Foreign Language Annals; 18(4): 333-340. http://dx.doi.org/ 10.1111/j.1944-9720.1985.tb01811.x

Kagan, D. M. (1992). Implication of research on teacher belief. Educational psychologist, 27(1), 65. http://dx.doi.org /10.1207/s15326985ep2701_6

Laufer, B. (1986). Possible changes in attitude towards vocabulary acquisition research. International Review of Applied Linguistics in Language Teaching, 24, 69-75.

Lortie, D. C. (2002). Schoolteacher: A sociological study, 2nd ed. Chicago, IL: The University of Chicago Press.

Milner, H. R. (2005). Stability and change in US prospective teachers' beliefs and decisions about diversity and learning to teach. Teaching and Teacher Education, 21(7), 767-786. Retrieved from: http://www.sciencedirect.com/science/article/pii/S0742051X05000697. http://dx.doi.org/10.1016/j.tate.2005.05.010

Minor, L.C., Onwuegbuzie, A.J., Witcher, A.E., \& James, T.L. (2001, November).Trends in teacher candidates' educational beliefs. Paper presented at the Annual Meeting of the Mid-south Educational Research Association, Little Rock, AR.

Nation, I. S. P. (1990).Teaching and learning vocabulary. Boston, MA: Heinle \& Heinle.

National Reading Panel. (2000). Report of the national reading panel: Teaching children to read. Washington, D.C.: National Institute of Child Health and Human Development.

Ozgun-Koca, S. A., \& Sen, A. I. (2006). The beliefs and perceptions of pre-service teachers enrolled in a subject-area dominant teacher education program about "effective education. Teaching and Teacher Education, 22(7):946-960. Retrieved 10 September 2012 from: http://www.sciencedirect.com/science/article/pii/S0742051X06000692.http://dx.doi.org/10.1 016/j.tate.2006.04.036

Pajares, M. F. (1992). Teachers' beliefs and educational research. Review of Educational Research, 62(3): 307-332. $\quad$ Retrieved $10 \quad$ September 2012 from: http://www.jstor.org/action/doBasicSearch?filter=\&Query $=\&$ Search. $x=5 \&$ Search. $y=8 \& w c=$ on

Palmer, D. (2006). Durability of changes in self-efficacy of pre service primary teachers. International Journal of Science Education, 28(6), 655-671. Retrieved 12 September 2012 from :http://www.tandfonline.com/toc/tsed20/28/6/. 
http://dx.doi.org/10.1080/09500690500404599

Pohan, C., \& Adams, C. (2007). Increasing family involvement and cultural understanding through a university school partnership. Action in Teacher Education, 29(1), 42-50. Retrieved 15 September 2012 from: http://www.tandfonline.com/doi/abs/10.1080/01626620.2007.10463438.http://dx.doi.org/10. $\underline{1080 / 01626620.2007 .10463438}$

Richards, J. C. (1980). The role of vocabulary teaching. In K. Croft (Ed.), Readings in English as a second language: For teachers and teacher trainers, 2nd ed. (pp. 424-438). Cambridge, MA: Winthrop.

Richards J. C., Gallo P. B., \& Renandya, W.A. (2001). Exploring teachers' beliefs and the processes of change. PAC Journal, 1 (1), 41-62. Retrieved 11 September 2012 from: http://www.pacteach.org/jirnl-v1/

Richardson, V. (1996). The role of attitudes and beliefs in learning to teach. In J. Sikula (Ed.), Handbook of research on teacher education. New York: Macmillan Library Reference USA, and Simon \& Schuster Macmillan.

Rifkin, B. (2000). Revising beliefs about foreign language learning. Foreign Language Annals, 33(4): 394-420. http://dx.doi.org /10.1111/j.1944-9720.2000.tb00621

Seliger, H. W; \& Shohamy, E. (1989). Second language research methods. Oxford: Oxford University Press.

Schmitt, N. (1997). Vocabulary learning strategies. In N. Schmitt, and M. McCarthy (Eds.) Vocabulary: Description, acquisition and pedagogy (pp. 199-227). Cambridge: Cambridge University Press.

Schmitt, N. (2000). Vocabulary in language teaching. Cambridge: Cambridge University Press.

Smith, M. K. (1941). Measurement of the size of general English vocabulary through the elementary grades and high school. Genetic Psychological Monographs, 24, 311-345.

Stahl, S. A. (1998). Four questions about vocabulary knowledge and reading and some answers. In C. Hynd (Ed.), Learning from text across conceptual domains (pp. 15-44). Mahwah, NJ: Lawrence Erlbaum Associates.

Stahl, S. A., \& Fairbanks, M. M. (1986). The effects of vocabulary instruction: A model based metaanalysis. Review of Educational Research, 56, 72-110. Retrieved 16 September 2012 from: http://www.jstor.org/action/doBasicSearch?filter=\&Query=\&Search.x $=5 \&$ Search. $y=8 \& w c=$ on

Thomas, L. F., \& Harri-Augstein, E. S. (1983). The self-organized learner as personal scientist: A conversational technology for reflecting on behavior and experience. In J. Adams-Webber \& J. C. Mancuso (Eds.), Applications of personal construct theory (pp. 223-250). Ontario: Academic Press Canada.

Torff, B. (2003). Developmental changes in teachers' use of higher-order thinking and content knowledge. Journal of Educational Psychology, 95(3), 563-569. Retrieved 12 September 2012 from: http://psycnet.apa.org/journals/edu/95/3/563/. http://dx.doi.org /10.1037/0022$\underline{0663.95 .3 .563}$

Zheng, H. (2009). A review of research on EFL pre-service teachers' beliefs and practices. Journal of Cambridge Studies; 4.(1): 79. Retrieved 10 September 2012 from: http://journal.acscam.org.uk/

\section{Acknowledgments}


I wish to express my gratitude firstly to merciful God, then to the Iranian EFL teachers and learners in this study, for their assistance in collecting the data, especially my own students. Most of all, I have been fortunate in having the comments from some research experts, for example, Professors Norbert Schmitt, Jack. C. Richards, Noam Chomsky, and especially, Paul Nation who helped me in solving research problems via E-mail. Thanks are also due to my father who encouraged me during the research. I also would like to express my special gratitude to my brother, who helped me in conducting the methodology. Without their help, the entire effort would not have been as finely tuned as it turned out to be.

\section{Author's Reference:}

Mozhgan Alsadat Ghaffarzadeh Hassankiadeh graduated with a MA degree in teaching language in September 2012. She has carried out research that has resulted in several publications and more currently under review. Her research interests lie in the teaching and testing of foreign languages and promoting the teaching/learning processes. She is a teacher in university as well as lower levels of education (high school) and loves teaching.

Email: ghaffarzadeh.mail@gmail.com

To cite this article:

Ghaffarzadeh, M. (2012). Function-based vs. meaning-based beliefs in teaching vocabulary. Bellaterra Journal of Teaching \& Learning Language \& Literature, 5(4), 20-41.

1 Third year of learning English as foreign language for learners. In Iran $3^{\text {rd }}$ level students are around 14 years old.

2 OPT refers to the Original Proficiency Test aimed to determine the learners' proficiency level in English.

3 The table is used to determine sample size for research activities aimed at educational measurement. Based on the table the sample was around 100 subjects from 150 persons in the statistical community. 


\section{Appendix A}

OUESTIONNAIRE ON TEACHERS' BELIEES ABOUT "TEACHING VOCABULARY"

This questionnaire is an attempt to gather information about Iranian English teachers' beliefs about teaching vocabulary. Your ideas are highly valued and your cooperation genuinely appreciated. The data gathered just serves this research and will remain confidential. Please feel free to share your ideas when answering the following items. If you are interested in the results of this survey, please leave your e-mail address in the end. A copy of the results will be sent to you afterwards.

Part A: Personal information:

Your name:

Your age:

1. How many years have you taught English? year(s)

2. Have you received any training on how to teach vocabulary learning strategies?

Yes $\square$ (Please specify what type of training: ) No

Part B: Close-ended questions

<Instructions> for each statement, there is one scale for you to place a tick. The following scale is for you to specify how useful you consider the strategy is to your students.

The scale:

\begin{tabular}{|c|c|c|c|c|}
\hline quite useful & Useful & $\begin{array}{c}\text { moderately } \\
\text { useful }\end{array}$ & $\begin{array}{c}\text { slightly } \\
\text { useful }\end{array}$ & not at all useful \\
\hline 5 & 4 & 3 & 2 & 1 \\
\hline
\end{tabular}

\begin{tabular}{|c|c|c|c|c|c|c|}
\hline Number & Belief description & 1 & 2 & 3 & 4 & 5 \\
\hline 1 & $\begin{array}{l}\text { To study a word with a picture of its meaning instead of } \\
\text { definition to remember it. }\end{array}$ & & & & & \\
\hline 2 & $\begin{array}{r}\text { To create one self's own mental images of a word's meaning to } \\
\text { remember it. }\end{array}$ & & & & & \\
\hline 3 & $\begin{array}{l}\text { To connect a word to a personal experience to remember it. } \\
\text { (e.g. Connecting the word snow to a memory of playing in the } \\
\text { snow for the first time) }\end{array}$ & & & & & \\
\hline
\end{tabular}

*** Note: The scales are :( $\mathbf{1}=$ not at all useful $\mathbf{2}=$ slightly useful $\mathbf{3}=$ moderately useful $\mathbf{4}=$ quite useful $\mathbf{5}=$ quite useful)

\begin{tabular}{|c|c|c|c|c|c|c|}
\hline Number & Belief description & 1 & 2 & 3 & 4 & 5 \\
\hline 4 & $\begin{array}{r}\text { To place the word in a group with other items based } \\
\text { on topic, theme or function (e.g. items about } \\
\text { food/art/request) }\end{array}$ & & & & & \\
\hline 5 & $\begin{array}{r}\text { To connect a word to its synonyms and antonyms to } \\
\text { remember it. }\end{array}$ & & & & & \\
\hline 6 & $\begin{array}{r}\text { ntic networks of a word to remember it. } \\
\text { E.g: }\end{array}$ & & & & & \\
\hline 7 & To use new words in sentences to remember them. & & & & & \\
\hline 8 & $\begin{array}{r}\text { To group words together within } \begin{array}{c}\text { a storyline to } \\
\text { remember them. }\end{array}\end{array}$ & & & & & \\
\hline 9 & $\begin{array}{l}\text { To use Keyword Method to remember words. } \\
\text { It means to find some words in Persian that sounds } \\
\text { like the English word that we want to teach and make } \\
\text { an imagination picture in learners' minds to remember } \\
\text { it better. }\end{array}$ & & & & & \\
\hline
\end{tabular}

Bellaterra Journal of Teaching \& Learning Language \& Literature. 5.4

(Nov-Dec 2012): 20-41. ISSN 2013-6196. 


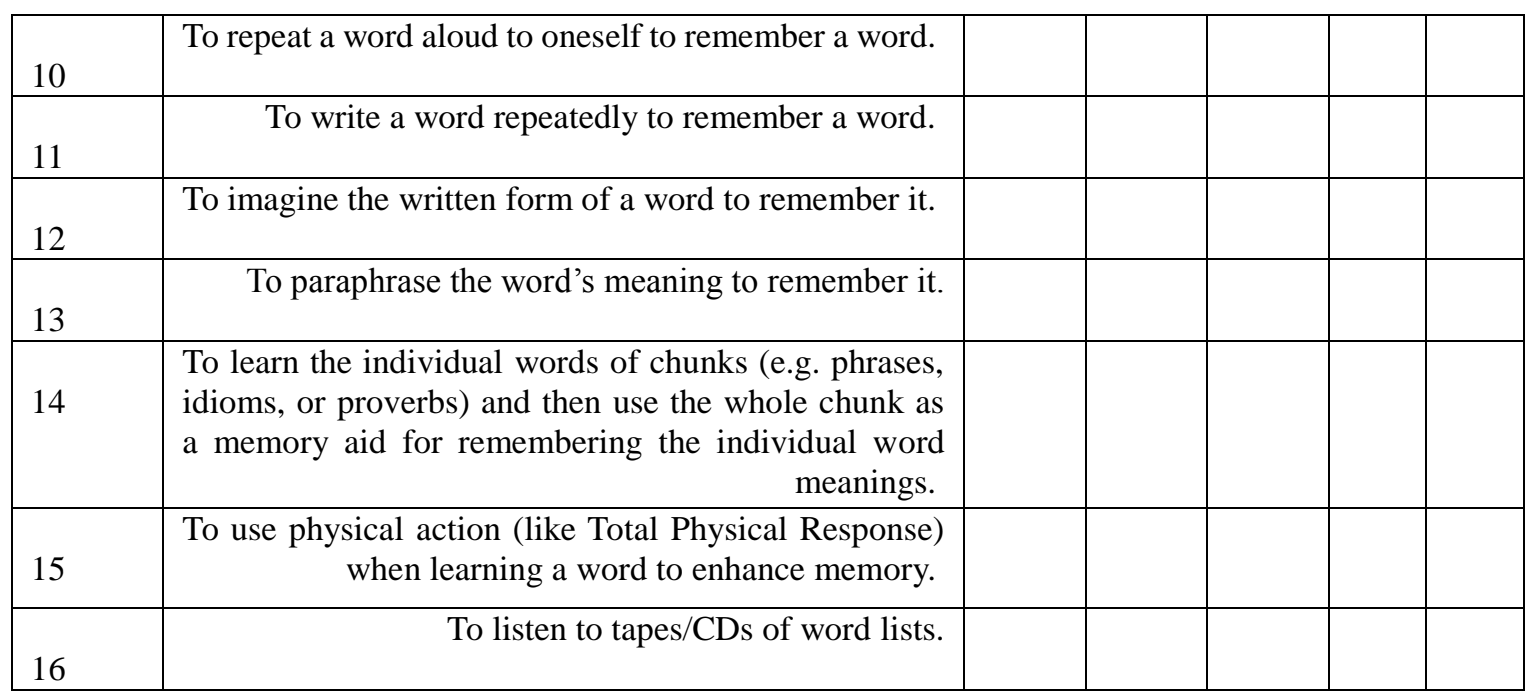

*** Note: The scales are :( $\mathbf{1}=$ not at all useful $\mathbf{2}=$ slightly useful $\mathbf{3}=$ moderately useful $\mathbf{4}=$ quite useful $\mathbf{5}=$ quite useful)

\begin{tabular}{|c|c|c|c|c|c|c|}
\hline Number & Belief description & 1 & 2 & 3 & 4 & 5 \\
\hline 17 & $\begin{array}{l}\text { To keep a vocabulary notebook to memorize the } \\
\text { vocabularies. }\end{array}$ & & & & & \\
\hline 18 & $\begin{array}{l}\text { To skip or pass an unknown word which seems } \\
\text { inessential for adequate comprehension of a passage. } \\
\text { And to use the text to understand its meaning. }\end{array}$ & & & & & \\
\hline 19 & $\begin{array}{l}\text { To concentrate on analyzing the part of speech (e.g. } \\
\text { noun/verb) of an unknown word for the first step. }\end{array}$ & & & & & \\
\hline 20 & $\begin{array}{l}\text { To look at the clause or sentence containing the } \\
\text { unknown word to find clues when guessing the } \\
\text { meaning. }\end{array}$ & & & & & \\
\hline 21 & $\begin{array}{l}\text { To examine how the clause containing the unknown } \\
\text { word relates to other clauses, sentences, or paragraphs } \\
\text { when guessing the meaning. (e.g. To pay attention to } \\
\text { conjunctions like but, because, if, when, or adverbs like } \\
\text { however, thus.) }\end{array}$ & & & & & \\
\hline 22 & $\begin{array}{l}\text { To make use of common sense and knowledge of the } \\
\text { world when guessing the meaning of an unknown } \\
\text { word. }\end{array}$ & & & & & \\
\hline 23 & $\begin{array}{r}\text { To make use of assumptions and mental images to } \\
\text { remember the new words. }\end{array}$ & & & & & \\
\hline 24 & Using the whole text to understand the unknown words & & & & & \\
\hline 25 & $\begin{array}{l}\text { Replace the unknown word with guessed meaning to } \\
\text { check if the sentence makes sense. }\end{array}$ & & & & & \\
\hline 26 & $\begin{array}{r}\text { To analyze affixes and roots of an unknown word in an } \\
\text { early stage when guessing. }\end{array}$ & & & & & \\
\hline 27 & To remember the most common affixes. & & & & & \\
\hline 28 & $\begin{array}{l}\text { Using extensive reading for example newspaper or } \\
\text { magazines. }\end{array}$ & & & & & \\
\hline
\end{tabular}

*** Note: The scales are :( $\mathbf{1}=$ not at all useful $\mathbf{2}=$ slightly useful $\mathbf{3}=$ moderately useful $\mathbf{4}=$ quite useful $\mathbf{5}=$ quite useful)

\begin{tabular}{|l|l|l|l|l|l|l|}
\hline Number & Belief description & 1 & 2 & 3 & 4 & 5 \\
\hline
\end{tabular}




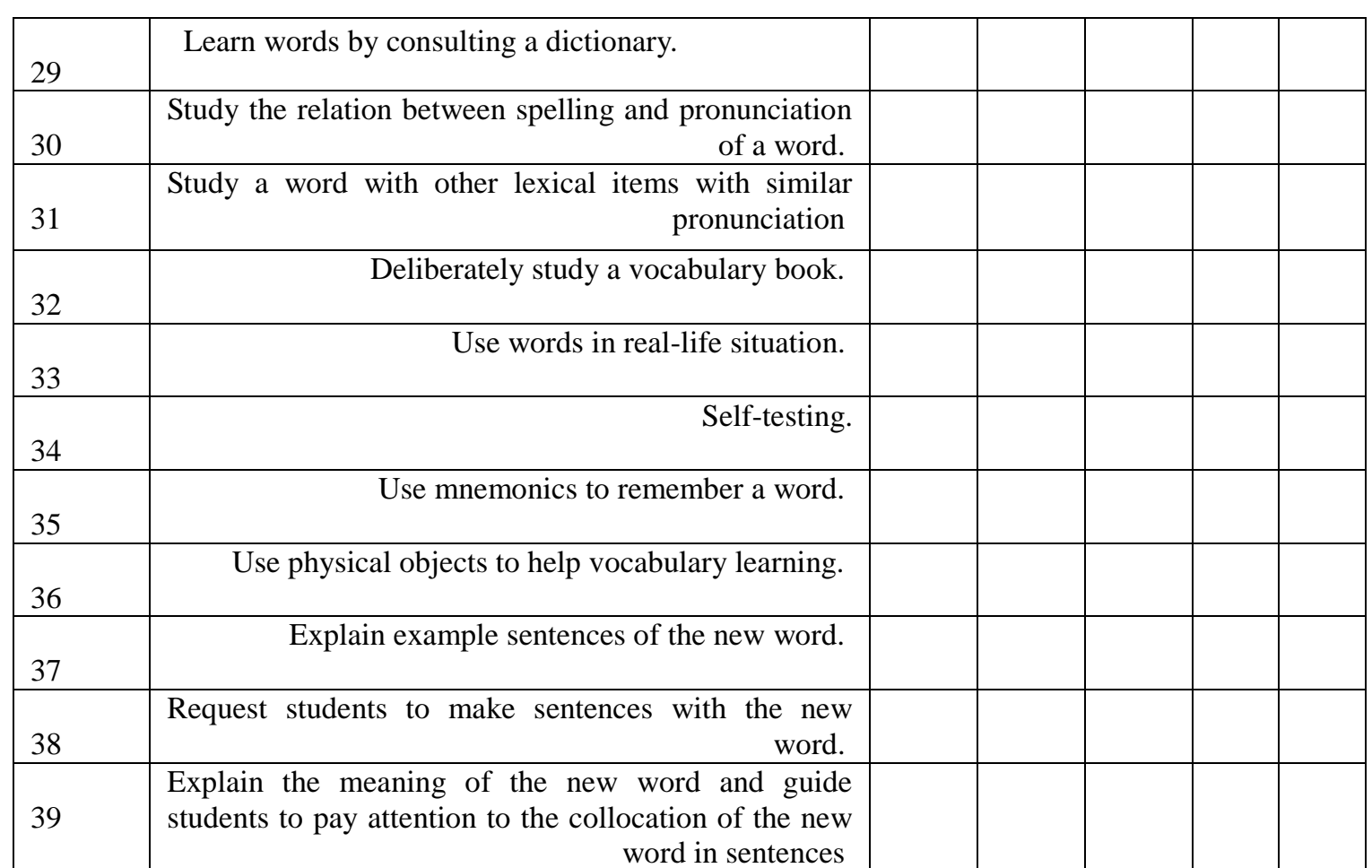

*** Note: The scales are: $(\mathbf{1}=$ not at all useful $\mathbf{2}=$ slightly useful $\mathbf{3}=$ moderately useful $\mathbf{4}=$ quite useful $\mathbf{5}=$ quite useful $)$

** If you are interested in the results, please leave your email:

Thanks a lot for joining and corporation $\odot$ 


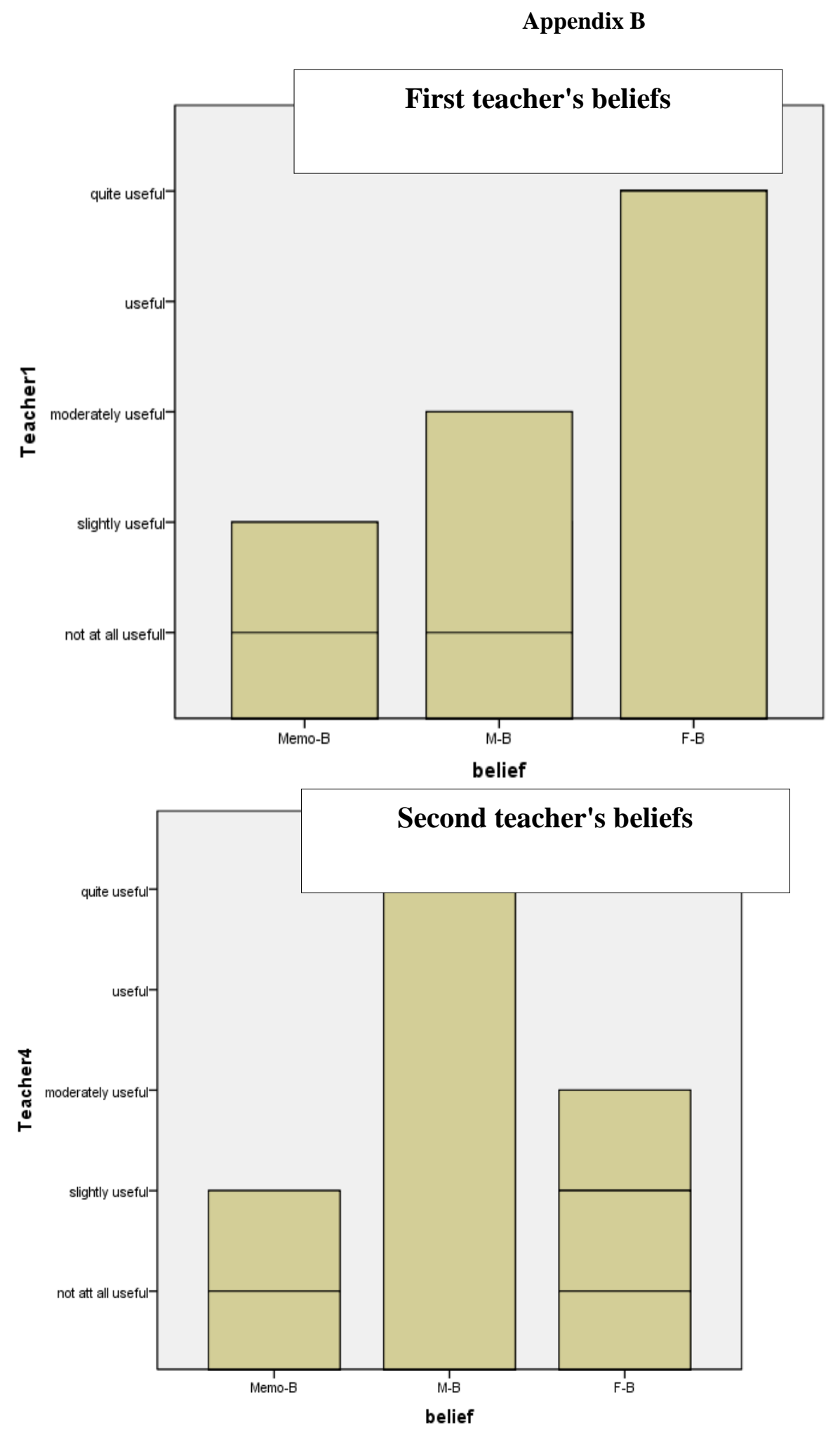




\section{Appendix C}

\begin{tabular}{|c|c|c|c|c|c|c|c|}
\hline $\begin{array}{l}\text { Final } \\
\text { subjects(learners) } \\
\text { NO. } 100\end{array}$ & study & $\begin{array}{l}\text { Pilot } \\
\text { subjects(learners) } \\
\text { NO. } 15\end{array}$ & study & $\begin{array}{l}\text { Final } \\
\text { subjects(teachers) } \\
\text { NO. } 4 \text { out of } 20\end{array}$ & study & $\begin{array}{l}\text { pilot } \\
\text { subjects(teachers) } \\
\text { NO. } 2 \text { out of } 4\end{array}$ & study \\
\hline $\begin{array}{l}50=M-B \\
50=F-B\end{array}$ & & $\begin{array}{l}5=\mathrm{M}-\mathrm{B} \\
5=\mathrm{F}-\mathrm{B}\end{array}$ & & $\begin{array}{l}1=M-B \\
1=F-B\end{array}$ & $\begin{array}{l}\text { hers } \\
\text { each } \\
\text { her }\end{array}$ & $\begin{array}{l}1=M-B \\
1=F-B\end{array}$ & \\
\hline
\end{tabular}

